\title{
Serum Bilirubin Levels in Overweight and Obese Individuals: The Importance of Anti-Inflammatory and Antioxidant Responses
}

\author{
Lovro Žiberna ${ }^{1}\left(\right.$, Zala Jenko-Pražnikar ${ }^{2}$ and Ana Petelin $2, * \mathbb{1}$ \\ 1 Institute of Pharmacology and Experimental Toxicology, Faculty of Medicine, University of Ljubljana, \\ SI-1000 Ljubljana, Slovenia; lovro.ziberna@mf.uni-lj.si \\ 2 Faculty of Health Sciences, University of Primorska, SI-6310 Izola, Slovenia; zala.praznikar@upr.si \\ * Correspondence: ana.petelin@upr.si; Tel.: +386-5-66-2469
}

Citation: Žiberna, L.;

Jenko-Pražnikar, Z.; Petelin, A. Serum Bilirubin Levels in Overweight and Obese Individuals: The Importance of Anti-Inflammatory and Antioxidant Responses. Antioxidants 2021, 10, 1352. https://doi.org/10.3390/ antiox10091352

Academic Editor: Cristina Bellarosa

Received: 23 July 2021

Accepted: 23 August 2021

Published: 26 August 2021

Publisher's Note: MDPI stays neutral with regard to jurisdictional claims in published maps and institutional affiliations.

Copyright: (c) 2021 by the authors. Licensee MDPI, Basel, Switzerland. This article is an open access article distributed under the terms and conditions of the Creative Commons Attribution (CC BY) license (https:/ / creativecommons.org/licenses/by/ $4.0 /)$.

\begin{abstract}
Obesity is a chronic condition involving low-grade inflammation and increased oxidative stress; thus, obese and overweight people have lower values of serum bilirubin. Essentially, bilirubin is a potent endogenous antioxidant molecule with anti-inflammatory, immunomodulatory, antithrombotic, and endocrine properties. This review paper presents the interplay between obesityrelated pathological processes and bilirubin, with a focus on adipose tissue and adipokines. We discuss potential strategies to mildly increase serum bilirubin levels in obese patients as an adjunctive therapeutic approach.
\end{abstract}

Keywords: adipokines; antioxidant; anti-inflammatory; bilirubin; obesity; overweight

\section{Introduction}

Bilirubin, the end product of heme metabolism, is a potent endogenous antioxidant with anti-inflammatory, immunomodulatory, antithrombotic, and endocrine properties [1-3]. Serum bilirubin concentrations depend on the complex interactions between bilirubin production, consumption (depending on oxidative stress and inflammation), metabolism, and elimination. Importantly, numerous studies have shown that serum bilirubin levels are inversely associated with obesity, metabolic syndrome (MetS), type 2 diabetes mellitus (T2DM), and other oxidative-stress-mediated diseases, including atherosclerosis [2,4,5]. Moreover, serum bilirubin levels were recently proposed as a potential predisease biomarker for developing metabolic syndrome in asymptomatic middle-aged individuals [6].

Obesity and overweight are considered pathological states of chronic low-grade inflammation with increased oxidative stress and altered endocrine signaling; therefore, these conditions result in lowered serum bilirubin levels [6]; on the other hand, reducing body weight leads to increased serum bilirubin levels [7,8]. Importantly, mild hyperbilirubinemia is associated with health benefits in overweight and obese individuals, as well as with lower adiposity $[9,10]$. This review addresses the current knowledge on how overweight and obesity affect bilirubin levels, along with the potential intervention strategies to modulate systemic bilirubin levels to alleviate the obesity-related negative effects on health.

\section{Inflammation in Obesity}

Obesity is the accumulation of excessive fat that harms health. Indeed, obesity and overweight are associated with several dysmetabolic conditions, including T2DM, nonalcoholic fatty liver diseases, cardiovascular diseases (CVDs), cancer, and neurodegenerative disorders, among others. Recently, the understanding of adipose tissue has undergone radical changes. Adipose tissue has been recognized as a heterogeneous tissue; indeed, it is composed of several cell types, including preadipocytes, mature adipocytes, fibroblasts, 
dendritic cells, mast cells, T-cells, endothelial cells, and macrophages [11]. Importantly, obesity is linked to a state of chronic low-grade inflammation, mainly due to proinflammatory cytokine secretion, macrophage infiltration, and disrupted function of tissue involved in glucose homeostasis [12]. Additionally, obesity is also associated with a significant increase in macrophage number $[13,14]$, which also contributes to the maintenance of the low-grade chronic inflammation state linked to obesity [15]. Macrophages are increased in adipose tissue during obesity due to several factors, free fatty acids, cholesterol, and lipopolysaccharide [16]. Macrophages can be classified, based on their surface expression or their cytokine or chemokine expression, into two main populations. M1 macrophages are associated with a proinflammatory profile and secrete proinflammatory cytokines (tumor necrosis factor $\alpha$ (TNF- $\alpha$ ), interleukin 1ß (IL-1ß), and interleukin 6 (IL-6)), whereas M2 macrophages are associated with tissue remodeling and inflammation resolution and secrete anti-inflammatory cytokines (IL-10, IL-1) $[17,18]$. Moreover, treating macrophages with a mix of glucose, palmitate, and insulin generates a unique macrophage proinflammatory phenotype that is different from M1 and secretes proinflammatory cytokines (TNF- $\alpha$, IL-1B), while the secretion depends on peroxisome-proliferator-activated receptor gamma (PPAR- $\gamma$ ) and p62 expression [19]. The mechanisms by which inflammation increases during obesity are still not fully understood. First, increased proinflammatory cytokine secretion contributes to insulin resistance and other complications related to obesity. Second, obesity not only promotes the infiltration of macrophages but also induces a shift in macrophage balance toward the M1 phenotype [17]; however, the adipose tissue is not the sole site of inflammation. In contrast, obesity-related inflammation occurs in many other tissues, such as the liver, muscle, hypothalamus, pancreatic islets, and the gut [20].

Adipose tissue was considered as an inert tissue having a primary role in controlling energy homeostasis. Additionally, it is now recognized that adipose tissue exhibits endocrine-regulatory properties and releases a cluster of bioactive substances, among them hormones and adipokines with pleiotropic functions [11,21-23]. Adipokines comprise, among others, classical cytokines (TNF $\alpha$, IL-6) and chemokines (IL-8, monocyte chemoattractant protein 1 (MCP-1), macrophage-inflammatory protein- $1 \alpha$, macrophageinflammatory protein- $2 \alpha$, stromal-cell-derived factor- 1 ), vasoactive and coagulation factors, regulators of lipoprotein metabolism, and proteins more specifically secreted by the adipocytes, such as leptin and adiponectin [24]. Adipocytes have been recognized as important sources of MCP-1, which was the first discovered human $B$-chemokine and is a recognized marker of adipose tissue dysfunction in obesity and T2DM [25]. An early study determined a link between obesity and inflammation and showed that adipose tissue synthesizes and releases the proinflammatory cytokine TNF- $\alpha$ [26]. Based on these findings, it was suggested that adipose tissue plays an important immune role and might be a major source of proinflammatory mediators, which initiate the development of low-grade chronic inflammation. Indeed, excess adipose tissue leads to high levels of proinflammatory cytokines TNF- $\alpha$ and IL- 6 and a sensitive marker of inflammation C-reactive protein (CRP) in circulating blood. TNF- $\alpha$ is synthesized as a $26 \mathrm{kDa}$ transmembrane protein. It has been shown that macrophages from the stromal vascular fraction are also the source of adipose-derived TNF- $\alpha$ and that its increased levels in obesity are due to the increased infiltration of adipose tissue with M1 macrophages [13]. Several studies have demonstrated that TNF- $\alpha$ impairs insulin signaling in hepatocytes and adipose tissue [27,28]. Moreover, IL-6 is a cytokine produced by many different cells. Approximately one-third of the IL6 detected in plasma is attributed to the production from white adipose tissue [29]. In adipocytes and hepatocytes, IL-6 has been demonstrated to impair insulin-induced insulin receptor and insulin receptor substrate 1 phosphorylation [30,31]. Furthermore, it has been shown that IL-6 stimulates hepatocytes to produce and secrete CRP, indicating a state of inflammation [32]. CRP is a sensitive marker of inflammation, which is synthesized and secreted mainly by the liver [32], the serum concentrations of which are higher among obese subjects $[33,34]$. Adiponectin is one of the most abundant adipokines produced by adipocytes and is involved in glucose and lipid metabolism [35]. In adipose tissue, 
adiponectin exerts an anti-inflammatory function by reducing macrophage infiltration and inhibiting the local production of numerous proinflammatory cytokines [36]. Leptin, which is almost exclusively secreted from adipocytes, controls food intake and energy expenditure and has atherogenic and growth properties [37]. Since the discovery of leptin, the number of adipokines has notably increased in the last years with new molecules such as omentin-1, chemerin, resistin, visfatin, apelin, adipocyte fatty acid-binding protein (AFABP), retinol-binding protein 4 (RBP4), among others [38]. Visfatin, originally identified as a pre-B-cell colony-enhancing factor (PBEF), is expressed in many cells and tissues act as a cytokine with immune regulatory action and as nicotinamide phosphoribosyltransferase (Nampt), an enzyme involved in the $\mathrm{NAD}^{+}$salvage pathway [39].

\section{Anti-Inflammatory Activity of Bilirubin}

Bilirubin has evident anti-inflammatory activity, and indeed several studies have shown an inverse relationship between serum bilirubin levels and CRP in overweight or diabetic subjects $[5,8,40,41]$. Since low-grade chronic inflammation plays an important role in adipose tissue, the liver, the aorta, the kidneys, and pancreatic cells, the antiinflammatory and antioxidative effects of bilirubin may likely contribute to the protective effect on vascular damage [1]. Recently, adipokines were studied along with serum bilirubin levels in normal and overweight asymptomatic adults. Importantly, there was an inverse relationship between serum bilirubin levels and proinflammatory cytokines (TNF- $\alpha$, IL6 , visfatin, and CRP) and a positive relationship between serum bilirubin levels and adiponectin [5,42].

Moreover, recently biliverdin treatment reduced the expression levels of M1 macrophage markers in adipose tissues induced by high-fat diet feeding mice. This indicates that bilirubin may improve high-fat-diet-induced insulin resistance by reducing chronic inflammation in adipose tissue [10].

Additionally, adiponectin exerts anti-inflammatory and antiatherogenic properties via its ability to stimulate vascular endothelial nitric oxide (NO) production [43]. Equivalently, more recent studies have shown the role of bilirubin in the activation of Akt and endothelial nitric oxide synthase leading to the synthesis of NO, which can also improve endothelial cell function and insulin resistance [44].

To address the potency of bilirubin responses, in several animal models of endotoxemia, septicemia, and ischemia-reperfusion injury, bilirubin exhibited significant antiinflammatory activity via mechanisms such as inhibiting the expression of adhesion molecules, suppressing the infiltration of inflammatory cells and reducing the levels of proinflammatory cytokines [45]. In another study, bilirubin also suppressed T cell proliferation and activation [46]. Overall, bilirubin has complex immunosuppressive effects [47]. A recent study also identified the neutrophil-to-lymphocyte ratio in blood as a variable that is negatively associated with total bilirubin levels [48].

Further studies are warranted to better elucidate bilirubin's mechanisms of action on adipocytes and to confirm the correlation between serum bilirubin and adipokines.

Table 1 presents adipokines and inflammatory markers that are altered in obese and overweight individuals and the relationships with serum bilirubin levels (if known).

Table 1. Adipokines and inflammatory markers that are altered in obese and overweight individuals and relationships with serum bilirubin levels.

\begin{tabular}{cccc}
\hline $\begin{array}{c}\text { Adipokines/Inflammatory } \\
\text { Markers }\end{array}$ & Bilirubin Relationship & State & Reference \\
\hline MCP-1 & Inverse relationship & $\begin{array}{c}\text { animal model (diet-induced } \\
\text { obesity in mice) }\end{array}$ & Dong et al., 2014 [49] \\
\hline TNF- $\alpha$ & Inverse relationship & overweight & Petelin et al., 2020 [42] \\
\hline IL-6 & Inverse relationship & overweight & Petelin et al., 2020 [42] \\
\hline
\end{tabular}


Table 1. Cont.

\begin{tabular}{|c|c|c|c|}
\hline $\begin{array}{l}\text { Adipokines/Inflammatory } \\
\text { Markers }\end{array}$ & Bilirubin Relationship & State & Reference \\
\hline CRP & Inverse relationship & Overweight/obese/diabetic & $\begin{array}{l}\text { Petelin et al., } 2020 \text { [42]; Yoshino } \\
\text { et al., } 2012 \text { [5]; Melissas et al., } 2006 \\
\text { [40]; Ohnaka et al., } 2010 \text { [41] }\end{array}$ \\
\hline Adiponectin & Positive relationship & overweight & Petelin et al., 2020 [42] \\
\hline Leptin & Inverse relationship & $\begin{array}{l}\text { animal model (diet-induced } \\
\text { obesity in mice) }\end{array}$ & Liu et al., 2015 [50] \\
\hline Omentin-1 & $\mathrm{N} / \mathrm{A}$ & $\mathrm{N} / \mathrm{A}$ & $\mathrm{N} / \mathrm{A}$ \\
\hline chemerin & Inverse relationship & $\begin{array}{c}\text { cancer patients (colorectal } \\
\text { carcinoma and hepatocellular } \\
\text { carcinoma) }\end{array}$ & Feder et al., 2019 [51] \\
\hline Resistin & Inverse relationship & overweight & Petelin et al., 2020 [42] \\
\hline Visfatin & Inverse relationship & overweight & Petelin et al., 2020 [42] \\
\hline Apelin & $\mathrm{N} / \mathrm{A}$ & $\mathrm{N} / \mathrm{A}$ & $\mathrm{N} / \mathrm{A}$ \\
\hline A-FABP & $\mathrm{N} / \mathrm{A}$ & $\mathrm{N} / \mathrm{A}$ & $\mathrm{N} / \mathrm{A}$ \\
\hline RBP-4 & $\mathrm{N} / \mathrm{A}$ & $\mathrm{N} / \mathrm{A}$ & $\mathrm{N} / \mathrm{A}$ \\
\hline
\end{tabular}

MCP-1 = monocyte chemoattractant protein 1 ; TNF- $\alpha=$ tumor necrosis factor $\alpha$; IL-6 = interleukin 6 ; CRP = C-reactive protein; $\mathrm{A}-\mathrm{FABP}=$ adipocyte fatty acid-binding protein; $\mathrm{RBP}-4=$ retinol-binding protein $4 ; \mathrm{N} / \mathrm{A}=$ non-applicable, no literature data.

\section{Oxidative Stress in Adipose Tissue Due to Obesity}

In addition to an increased proinflammatory response in adipose tissue due to overweight and obesity, excessive production of reactive oxygen species (ROS), decreased antioxidant activity, and higher oxidative stress, especially in white adipose tissue, are also observed in overweight and obese individuals [52-54].

In overweight and obese individuals, oxidative stress in adipose tissue is mainly induced by the catalytic activity of the enzyme nicotinamide adenine dinucleotide phosphate (NADPH) oxidase (NOX) or by dysfunctional mitochondrial oxidative phosphorylation [52,55]. Electron transfer through the electron transfer chain or from NADPH to oxygen generates superoxide anions, which are the primary ROS species that are further converted to $\mathrm{H}_{2} \mathrm{O}_{2}$; however, $\mathrm{ROS}$ include chemically diverse compounds (nitric oxide, peroxynitrite, hypochlorous acid, singlet oxygen, hydroxyl radical) with diverse physiological and pathological effects.

Several studies have shown that NOX-derived ROS production is associated with the early stages of obesity, while mitochondrial-derived ROS production is associated with the late stages of obesity [55]. NOX is a plasma-membrane-bound enzyme involved in the transfer of electrons from NADPH to oxygen and is the main generator of ROS in adipocytes [56]. In obese mice, mRNA expression levels of NOX subunits were increased only in adipose tissue, which was associated with increased ROS production [53], while adipose-specific deletion of NOX4 attenuated adipose tissue inflammation and early onset of insulin resistance in diet-induced obese mice [57]. Moreover, in cultured 3T3-L1 adipocytes, high levels of free fatty acids (FFAs) and glucose increased ROS production via NOX activation $[53,58]$, whereas treatment with NOX inhibitors or silencing of NOX4 ameliorated this effect by reducing ROS generation [53,58].

In overweight and obese individuals, oxidative stress in adipose tissue is also induced by dysfunctional mitochondrial oxidative phosphorylation. Conditions that favor mitochondrial superoxide production include a reduction in electron carrier pools associated with the mitochondrial respiratory chain (NADH, flavins, ubiquinone), high proton motive force, and increased oxygen consumption within mitochondria [59]. Overeating delivers excess electrons to the respiratory chain, while lack of physical activity and low ATP demand promote a high proton motive force at a low respiratory rate, leading to mito- 
chondrial superoxide formation and oxidative stress. In a morbidly obese state, adipocytes utilize FFAs from triglyceride stores via excessive lipolysis for energy because of glucose deprivation due to insulin resistance [55]. Excess FFAs lead to an excess of electrons in the electron transport chain during oxidative phosphorylation, resulting in their exit and the generation of $\mathrm{O}_{2}{ }^{-}$followed by the production of other ROS molecules [60]. Increased $\beta$-oxidation also leads to an increased mitochondrial $\mathrm{NADH} / \mathrm{NAD}^{+}$ratio, resulting in increased activation of protein kinase $\mathrm{C}$ (PKC). Activated PKC then contributes to ROS production by increasing the activity of NADPH oxidase (NOX) [60].

Excessive production of mitochondrially derived ROS is also associated with exacerbation of inflammation through the release of inflammatory cytokines and proinflammatory transcription factors such as nuclear factor kappa B (NF-kB) and activator protein-1, which in turn increases ROS production [61]. Moreover, activated PKC induces NF- $\mathrm{kB}$ and tumor growth factor-beta activation, establishing a link between oxidative stress and inflammation. The phenomenon of increased proinflammatory response and oxidative stress in obese states contributes significantly to the development of other metabolic complications such as T2DM, cardiovascular disease, and certain types of cancer [62].

\section{Antioxidant Activity of Bilirubin}

Bilirubin is a potent endogenous antioxidant at its physiological concentrations. Bilirubin can scavenge reactive oxygen species by oxidizing itself to biliverdin. Then, biliverdin is recycled back to bilirubin by biliverdin reductase [63]. This cycle enables nanomolar concentrations of bilirubin to protect cells from the 10,000-fold molar excess of oxidants when both substances are added exogenously to cell culture [64].

In addition to the direct ROS scavenging activity, bilirubin can further decrease oxidative burden in the intracellular compartment by inhibiting NADPH oxidase complexes, which are the major source of oxidative stress in adipocytes $[65,66]$. Moreover, activated macrophages in hypertrophic adipose tissue express NADPH oxidase and further increase oxidative stress. Altogether, the redox imbalance leads to adipocyte dysfunction in obesity [56]. Importantly, bilirubin, via its antioxidant activity, can prevent adipocyte hypertrophy via its hypothalamic effect and can improve the function of adipocytes that have already hypertrophied $[9,56]$.

Obesity and MetS also impair vascular endothelial function; however, bilirubin also acts as an intracellular antioxidant in the endothelia of both arterial and venous systems, with $\mathrm{EC}_{50}$ values in the nanomolar range [67].

\section{Bilirubin as a Signaling Molecule Involved in Energy Homeostasis}

In addition to bilirubin's known role as an antioxidant and anti-inflammatory molecule, it is now recognized that unconjugated bilirubin is also a potent endogenous activator of several ligand-activated transcriptional factors crucially involved in metabolic homeostasis, including peroxisome proliferator-activated receptor alpha (PPAR- $\alpha$ ), aryl hydrocarbon receptor, constitutive androsterone receptor (CAR), liver $X$ receptors (LXRs), and pregnane $\mathrm{X}$ receptor (PXR) [68].

PPARs, a class of nuclear receptors, function as fatty acid and eicosanoid sensors that regulate multiple pathways involved in lipid and glucose metabolism, as well as overall energy metabolism, playing an important role in the pathogenesis of obesity and other metabolic diseases [69]. Interestingly, there are structural similarities between bilirubin and known PPAR $\alpha$ ligands [70]. Furthermore, bilirubin explicitly docks to the PPAR- $\alpha$ ligand-binding domain to regulate transcriptional responses. PPAR- $\alpha$ is highly active in the liver, adipose tissue, kidney, heart, and muscle tissue [71], where it regulates the adaptive response to prolonged fasting by controling the process of ketogenesis, fatty acid transport, fatty acid binding, fatty acid activation, and mitochondrial fatty acid- $\beta$ oxidation [72]. Genomic studies have shown that PPAR- $\alpha$, as a master regulator of lipid metabolism, has several target genes; classic genes include acyl-CoA oxidase, thiolase, fatty acid transport protein, carnitine palmitoyltransferase I, and peroxisome proliferator- 
activated receptor-gamma coactivator 1-alpha [72]. Recent studies on bilirubin-induced transcriptome responses showed that it selectively acts via PPAR- $\alpha$, inducing gene transcription that activates mitochondrial function and $\beta$-oxidation to utilize fats for energy and reduces body weight [70,73-75]. In addition, hyperbilirubinemia in mice on a high-fat diet increased the mitochondrial number and hyperphosphorylation of PPAR- $\alpha$ compared to controls, thereby indicating that bilirubin is a metabolic hormone that controls white adipose tissue expansion and reduces hypertrophy and glucose intolerance [76]. Furthermore, bilirubin nanoparticles induce hepatic fat utilization, increase plasma ketones, and reduce hepatic steatosis [77].

In addition to bilirubin's direct action as a PPAR- $\alpha$ ligand, bilirubin acts via FABP1, CAR, and LXRs [68]. CAR has recently been identified as a therapeutic target for obesity and its associated metabolic disorders $[78,79]$. LXRs are sterol sensors that mainly regulate cholesterol, fatty acids, and glucose homeostasis, and may inhibit the development of atherosclerosis but promote lipogenesis in the liver [80]. Bilirubin acts as a ligand transactivator of CAR and PXR to increase the expression of target genes responsible for its disposal [81], and also to increase the expression of genes involved in energy metabolism [82]. On the other hand, LXR is under negative control of bilirubin and systemic bilirubin application was shown to attenuate dyslipidemia in diabetic rats [83].

Figure 1 illustrates the anti-inflammatory and antioxidant actions of bilirubin and its properties as a signalling molecule in adipose tissue.

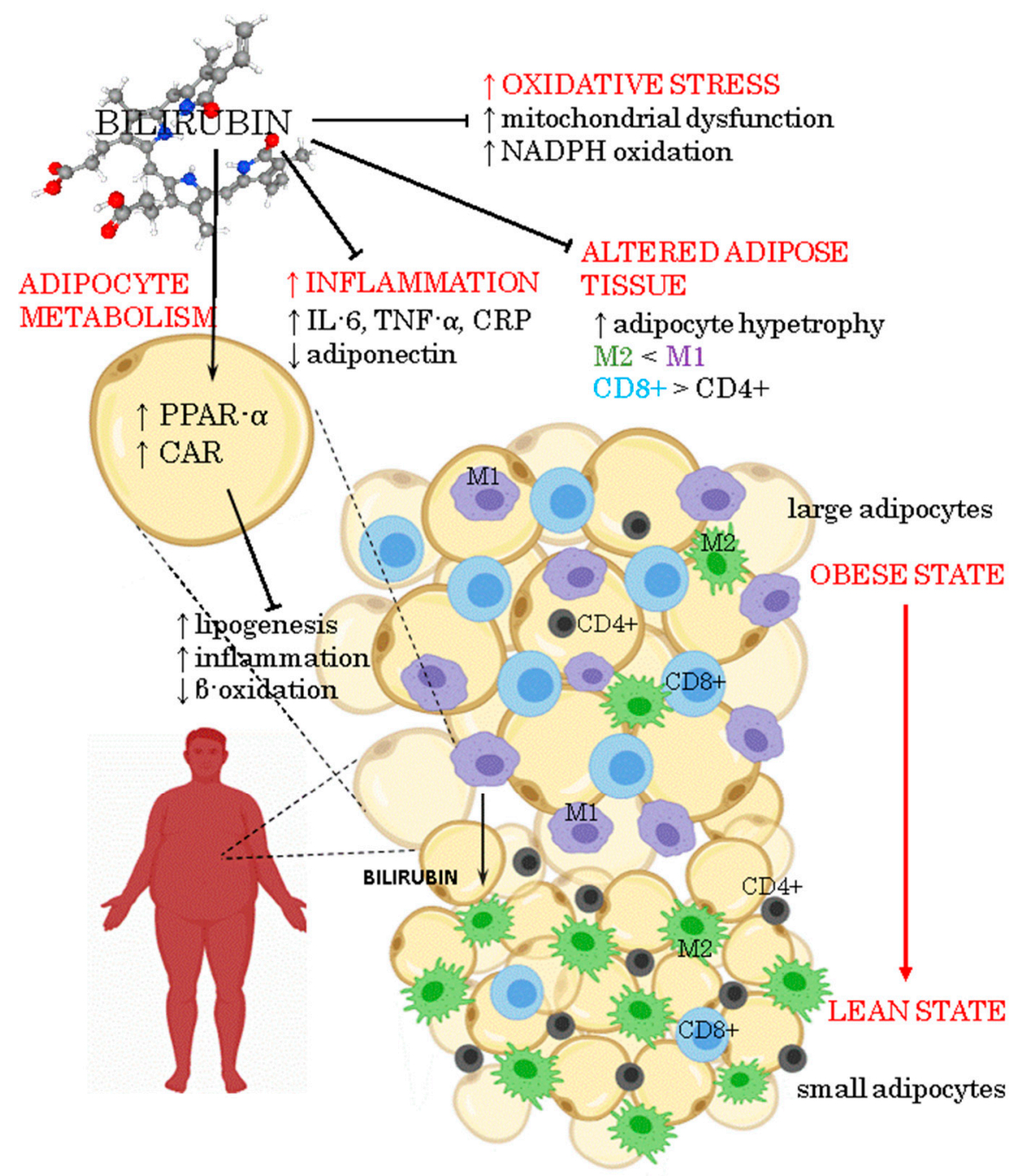

Figure 1. Pleiotropic effects of bilirubin on obesity. 


\section{Potential Interventions to Modulate Serum Bilirubin Levels in Obesity}

Strategies to mildly increase serum bilirubin levels are important, especially in individuals most at risk. It is important to note that already mild elevation of bilirubin levels can have important clinical benefits. For example, each $0.1 \mathrm{mg} / \mathrm{dL}(1.7 \mu \mathrm{M})$ increase in serum bilirubin levels was associated with a $6 \%$ reduction in the risk of peripheral arterial disease [84]. Each micromolar increase in serum bilirubin was associated with an $11 \%$ decrease in the odds of developing diabetes [85] and decreased systolic blood pressure by $0.13 \mathrm{~mm} \mathrm{Hg}$ [86]. Both of these two conditions, diabetes mellitus and hypertension, are correlated with obesity.

Low serum bilirubin levels (hypobilirubinemia) are harmful and can lead to various cardiovascular complications and possibly stroke [87]. Lower bilirubin levels contribute to increased low-density lipoprotein oxidation in obese children and adolescents, predisposing them to increased cardiovascular risk [88]. Indeed, serum bilirubin concentrations were significantly lower in patients with acute myocardial infarction [89]. Moreover, low serum bilirubin levels $(<7 \mu \mathrm{M})$ are correlated with the significant increase in the relative risk of coronary heart disease [90] and with the risk of overall mortality [91]; therefore, strategies to increase serum bilirubin levels represent an important approach to ameliorate several obesity-mediated or obesity-correlated diseases.

Figure 2 illustrates different interventions to modulate serum bilirubin levels in obesity.

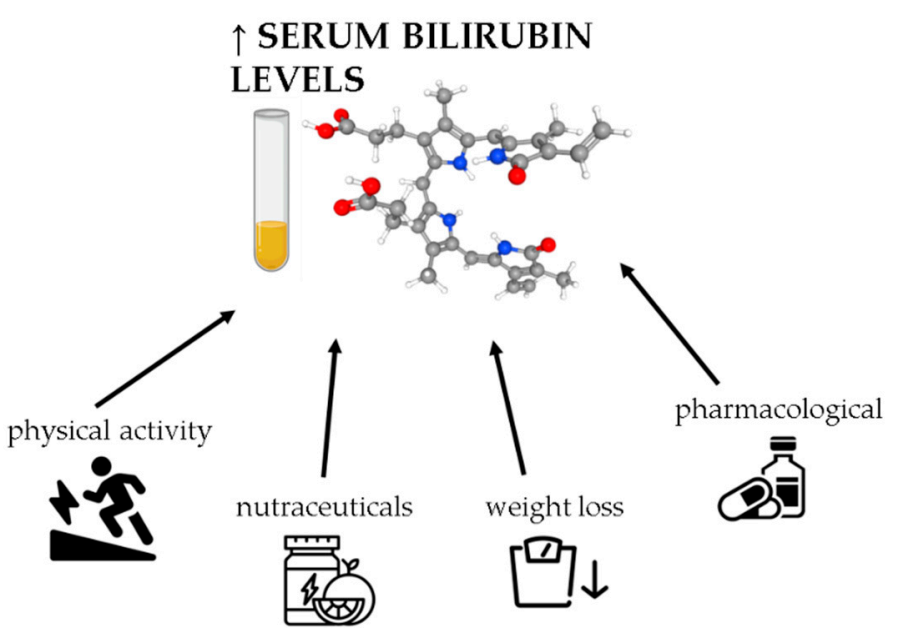

Figure 2. Approaches to modulate serum bilirubin levels in obesity. Bilirubin can be upregulated by different types of interventions, including exercise, diet, pharmacological, and nutraceutical interventions.

\subsection{Weight Loss}

Weight loss is the most obvious approach for treating obesity, as well as in the modulation of serum bilirubin levels. Low caloric intake in obese patients in the period between one and two months increased serum bilirubin levels by $18-45 \%$ [92,93]. Similarly, shortterm weight loss effectively increased bilirubin levels with an increase in bilirubin as a linear function of weight change [8]. The effect was higher in men than in women; namely, each $1 \%$ increase in weight loss was associated with a $0.21 \mu \mathrm{M}$ increase in serum bilirubin levels in men and a $0.11 \mu \mathrm{M}$ increase in women [8]. Additionally, there is a direct correlation between BMI and serum bilirubin levels in asymptomatic overweight individuals [6], as well as in obese patients [48].

In addition to weight loss, changes in body composition are also important. Body fat percentage was inversely correlated with bilirubin in obese patients but not in controls [94].

\subsection{Nutraceutical Interventions}

Diet affects serum bilirubin levels. A higher intake of flavonoid-rich fruits and vegetables was significantly associated with higher total serum bilirubin [95], while a higher 
intake of fried and fast foods was significantly associated with lower bilirubin levels [96,97]. Indeed, we have previously shown that higher intake of total fatty acids is associated with lower serum bilirubin, while higher intake levels of vitamin $C$ and folic acid are associated with higher bilirubin levels [6].

It has been shown that many natural compounds, including curcuminoids, flavonoids, epigallocatechin-3-gallate, genistein, caffeic acid, resveratrol, and natural coumarins, can induce the expression of heme oxygenase-1 (HO-1) [98-100]. Indeed, in our previous work, we showed that consumption of buckwheat porridge rich in flavonoids for four weeks resulted in higher serum bilirubin levels in subjects with MetS [101]. In addition to polyphenols, other bioactive natural compounds also exert HO-1 inducing activity. Our group recently showed that peroral application of lyophilized royal jelly significantly increased serum bilirubin compared to placebo after 8 weeks in asymptomatic overweight adults [102]. The bioactive compound was likely 4-hydroperoxy-2-decenoic acid ethyl ester, a royal jelly fatty acid derivative that significantly induced HO-1 expression in cell culture [103].

Moreover, the HO-1 enzyme combines the physiology of the bilirubin and adiponectin axis responses. Oxidative stress and inflammation upregulate the level of inducible HO-1, thereby increasing total bilirubin levels [104]. Furthermore, the HO-1 system is also involved in enhancing adiponectin synthesis and release [105]. Interestingly, HO-1 induction was reported to reduce visceral and subcutaneous obesity in diabetic and obese mice [106]. Likewise, increasing intracellular bilirubin levels via HO-1 induction in adipocytes improved adipocyte function and adipose remodeling by increasing adiponectin levels [107]. In a similar study, HO-1 induction also altered the physical appearance of adipocytes from a few large to many smaller adipocytes [108]. Additionally, the HO-1 induction was found to be beneficial in obesity by inhibiting adipogenesis by preventing the creation of adipose tissue from mesenchymal stem cells [109].

In addition to stimulatory effects on HO-1, many natural bioactive compounds, including epigallocatechin gallate, flavonoids, silymarin, flavonolignans, and various herbal supplements, exhibit inhibitory effects on UDP glucuronosyltransferase family 1 member A1 (UGT1A1) [85,110,111], thereby leading to hyperbilirubinemia. On the other hand, a bilirubin-lowering effect has been observed with the intake of citrus fruits, cruciferous vegetables, onions, garlic, and coffee, probably due to the UGT1A1-inducing activities [85,112].

Another potential dietary approach is to enhance the systemic pool of tetrapyrroles with bilirubin-like substances. In vitro experiments on cell cultures using the edible blue alga Spirulina platensis, which is rich in tetrapyrrolic compounds closely related to bilirubin, led to improved intracellular redox status and antiproliferative effects [113].

\subsection{Physical Activity}

One of the first reports showed that any type of exercise, either habitual or irregular, increased total bilirubin levels compared with the group of individuals who do not exercise [114]. Indeed, intensive regular exercise, as seen in athletes, is correlated with elevated concentrations of total bilirubin [115]. Animal experiments showed that exercise stimulates pathways that raise serum bilirubin levels through alterations in the levels of hepatic enzymes; namely, increasing the expression of biliverdin reductase and consequently increasing bilirubin synthesis, as well as decreasing the expression of UGT1A1, which converts the biologically active unconjugated bilirubin into the non-active conjugated form [116].

The intensity of the exercise is important in increasing the serum bilirubin levels. An intervention study on previously sedentary postmenopausal women showed that only a high dose of exercise training of at least 12 kilocalories per kilogram per week of exercise training at an intensity of 50\% of aerobic capacity resulted in a modest elevation of serum bilirubin levels, whereas lower training loads had no effect [117]. Accordingly, asymptomatic overweight and obese middle-aged individuals who had better measured aerobic body capabilities had higher serum bilirubin levels [6]. 
Some studies have shown no effects of exercise on the modulation of serum bilirubin levels. A study on women with abdominal obesity doing endurance or endurance-strength exercise for 60 min 3 times / week for 3 months did not alter total serum bilirubin levels [118]. Moreover, endurance-strength exercise even decreased indirect bilirubin [118]. Similarly, another study showed that moderate-to-vigorous physical activity increased bilirubin levels only in insulin-resistant individuals but not in insulin-sensitive individuals [119].

\subsection{Pharmacological Approaches}

Diverse pharmacological strategies can modulate serum bilirubin levels via the application of drug compounds that bind to the selected molecular targets, affecting the following bilirubin homeostasis processes: (i) the synthesis of bilirubin ( $\mathrm{HO}-1$, biliverdin reductase); (ii) the metabolism of bilirubin UGT1A1, which converts the active unconjugated form of bilirubin into non-active conjugated bilirubin; (iii) the uptake of bilirubin via membrane transporters (bilitranslocase, organic anionic transporter OATP1B1) into the hepatic and other cells; (iv) the distribution of bilirubin throughout the body via serum albumin binding.

To increase the synthesis of bilirubin, several potential drug compounds can increase the level of HO-1, thereby leading to either increases in intracellular and serum bilirubin levels [120], namely nonsteroidal anti-inflammatory drugs such as acetylsalicylic acid and coxibs and hypolipidemic drugs such as statins, fibrates, and niacin [121]. In mouse experiments, atorvastatin and rosuvastatin increased expression of $\mathrm{HO}-1$, consequently increasing serum bilirubin levels and total antioxidant status [122]. Importantly, 60-70\% of patients with obesity are dyslipidemic, with statins representing the cornerstone of dyslipidemia treatments [123].

Another approach to mildly elevated bilirubin levels is to reduce bilirubin metabolism by inhibition of UGT1A1. Atazanavir is a drug compound used clinically for treating HIV-infected patients; however, it is also a well-established inhibitor of UGT1A1 leading to increased unconjugated bilirubin levels [124]. Indeed, patients on atazanavir therapy have less myocardial infarction compared with other pharmacotherapy strategies [125]. Atazanavir treatment for 3 days in non-HIV patients with T2DM increased average serum bilirubin levels from 7 to $64 \mu \mathrm{M}$, increased total plasma antioxidant capacity, and improved endothelium-dependent vasodilation [126]. Other drugs known to inhibit UGT1A1 are cancer treatment drugs, such as kinase inhibitors and topoisomerase I inhibitors, among others [121]; however, these latter drugs are less suitable for modulating serum bilirubin levels in obese patients due to their serious adverse effects.

There is also a large group of drugs that inhibit the uptake of bilirubin into the liver and other cells. Inhibition of entry into liver cells will decrease bilirubin metabolism, thereby increasing unconjugated bilirubin, which is also the bioactive form. Some drug compounds can act as inhibitors of bilitranslocase, a membrane protein that acts as a transporter of bilirubin from blood to liver cells [127]. Some promising candidate drugs are the antihypertensive drug hydrochlorothiazide and the nonsteroidal anti-inflammatory drug sulindac [127]. In addition to the bilitranslocase, bilirubin can enter cells using OATP1B1 transporter, which interacts with more than 700 drug compounds; some reported candidate drugs are statins, nonsteroidal anti-inflammatory drugs, $\beta$-blockers, cyclosporin A, antivirals, sartans, glitazones, and many others [121].

Lastly, several drug compounds compete with bilirubin for albumin binding, displacing unconjugated bilirubin from the binding site on albumin, leading to transient hyperbilirubinemia [128]. For example, ibuprofen replaces bilirubin from albumin and is also widely prescribed with a good safety profile [129].

\section{Prospective Practice of Bilirubin Regulation in Obesity Treatment}

There are several considerations in the prospective use of therapeutic approaches to modulate serum bilirubin levels in obese patients. First, it remains an open question whether the serum bilirubin level is a causal therapeutic target for obesity and CVDs, 
or rather a phenomenon driven by unmeasured confounding or reverse causation [130]. In this regard, large amounts of data have been obtained from several observational epidemiological studies, whereas there is a lack of controlled clinical trials offering the highest clinical evidence. Second, a recent large retrospective cross-sectional study on severely obese children showed that bilirubin is inversely associated only with some components of MetS, such as high blood pressure, high triglycerides, waist circumference, waist-height ratio, CRP levels, and HOMA-IR index; interestingly, no association between serum bilirubin and MetS or fatty liver was found [131]. This study showed that bilirubin is not protective in the presence of severe obesity (BMI > 95th percentile), whereas there is a greater number of published studies focused on the whole spectrum of individuals from overweight to obese. This raises the question of whether the role of bilirubin in obesity is more of a preventive nature or can also be therapeutic.

In contrast to most published studies, one study also reported that serum bilirubin concentrations were not negatively associated with inflammatory biomarkers or a protective lipid profile when conducting retrospective epidemiological investigations [132]; however, this study was conducted on all adults referred for routine medical check-ups, and most of the participants were indeed healthy with low CRP values and normal lipid profiles; thus, the protective effects of mildly increased serum bilirubin levels in overweight and obese individuals could have been masked.

The idea of using mildly elevated serum bilirubin levels in obesity treatment would require controlled clinical trials; however, since several drug candidates are already registered, this approach would involve drug repurposing with a known drug safety profile and potential adverse effects, whereas nutraceutical, diet, and physical activity approaches involve even more straightforward research processes. Moreover, it is important to mention that such interventions would be long term and must be individually tailored considering the severity of obesity and other CVD-related parameters.

Importantly, strong caution is required when using intervention approaches to increase bilirubin levels to prevent markedly elevated bilirubin levels, which might be toxic; thus, continuous monitoring of bilirubin levels in each individual must be employed, since the bilirubin levels largely depend on the individual genotype.

Our review article assesses the role of the serum bilirubin level as an additional clinical target that can be both modified and routinely measured, while considering that obesity is a multifactorial and complex disease with no single-hit druggable target; however, there is also a simple logic in the suggested approach. In obesity, chronic inflammation, increased oxidative stress, altered adipose tissue, and altered adipocyte metabolism occur; importantly, bilirubin is a strong endogenous antioxidant molecule with anti-inflammatory and adipocyte-modifying properties.

\section{Conclusions}

Overweight and obese adults have lower serum bilirubin values compared to normalweight individuals. Since bilirubin is an endogenous molecule with antioxidant, antiinflammatory, antithrombogenic, endocrine, and many other activities, the modulation of serum bilirubin levels represents a novel therapeutic approach. Mildly increased serum bilirubin levels will protect other organs and directly affect the adipose tissue and its adipokine secretion pattern. In our opinion, the modulation of serum bilirubin levels will be an effective adjunctive therapy for obesity that can improve several obesity-induced pathological conditions.

Author Contributions: Conceptualization, L.Ž., Z.J.-P. and A.P.; methodology, L.Ž., Z.J.-P. and A.P.; investigation, L.Ž., Z.J.-P. and A.P.; resources, L.Ž., Z.J.-P. and A.P.; data curation, L.Ž., Z.J.-P. and A.P.; writing—original draft preparation, L.Ž., and A.P.; writing—review and editing, L.Ž., Z.J.-P. and A.P.; visualization, L.Ž., Z.J.-P. and A.P.; supervision, L.Ž., and A.P.; funding acquisition, L.Ž., Z.J.-P. and A.P. All authors have read and agreed to the published version of the manuscript. 
Funding: The authors acknowledge that this work was financially supported by the Slovenian Research Agency under research project J3 8209 (Bilirubin as a Protective Factor Against Chronic Degenerative Disease: Biomarker and Potential for Pharmacological Modulation) and research programs P1 0386 and P3 0067. Additionally, we were financially supported by the University of Primorska, Faculty of Health Sciences, for the project entitled A Multidisciplinary Approach in the Treatment of Obesity.

Conflicts of Interest: The authors declare no conflict of interest. The funders had no role in the design of the study; in the collection, analyses, or interpretation of data; in the writing of the manuscript, or in the decision to publish the results.

\section{References}

1. Inoguchi, T.; Sonoda, N.; Maeda, Y. Bilirubin as an important physiological modulator of oxidative stress and chronic inflammation in metabolic syndrome and diabetes: A new aspect on old molecule. Diabetol. Int. 2016, 7, 338-341. [CrossRef]

2. Vitek, L. The role of bilirubin in diabetes, metabolic syndrome, and cardiovascular diseases. Front. Pharmacol. 2012, 3, 55. [CrossRef] [PubMed]

3. Vitek, L.; Tiribelli, C. Bilirubin: The yellow hormone? J. Hepatol. 2021. [CrossRef] [PubMed]

4. Nano, J.; Muka, T.; Cepeda, M.; Voortman, T.; Dhana, K.; Brahimaj, A.; Dehghan, A.; Franco, O.H. Association of circulating total bilirubin with the metabolic syndrome and type 2 diabetes: A systematic review and meta-analysis of observational evidence. Diabetes Metab. 2016, 42, 389-397. [CrossRef] [PubMed]

5. Yoshino, S.; Hamasaki, S.; Ishida, S.; Kataoka, T.; Yoshikawa, A.; Oketani, N.; Saihara, K.; Okui, H.; Shinsato, T.; Ichiki, H.; et al. Relationship between bilirubin concentration, coronary endothelial function, and inflammatory stress in overweight patients. J. Atheroscler. Thromb. 2011, 18, 403-412. [CrossRef]

6. Jenko-Praznikar, Z.; Petelin, A.; Jurdana, M.; Ziberna, L. Serum bilirubin levels are lower in overweight asymptomatic middleaged adults: An early indicator of metabolic syndrome? Metabolism 2013, 62, 976-985. [CrossRef] [PubMed]

7. Friis, R.; Vaziri, N.D.; Akbarpour, F.; Afrasiabi, A. Effect of rapid weight loss with supplemented fasting on liver tests. J. Clin. Gastroenterol. 1987, 9, 204-207. [CrossRef]

8. Andersson, C.; Weeke, P.; Fosbol, E.L.; Brendorp, B.; Kober, L.; Coutinho, W.; Sharma, A.M.; Van Gaal, L.; Finer, N.; James, W.P.; et al. Acute effect of weight loss on levels of total bilirubin in obese, cardiovascular high-risk patients: An analysis from the lead-in period of the Sibutramine Cardiovascular Outcome trial. Metabolism 2009, 58, 1109-1115. [CrossRef]

9. DiNicolantonio, J.J.; McCarty, M.F.; O'Keefe, J.H. Antioxidant bilirubin works in multiple ways to reduce risk for obesity and its health complications. Open Heart 2018, 5, e000914. [CrossRef]

10. Takei, R.; Inoue, T.; Sonoda, N.; Kohjima, M.; Okamoto, M.; Sakamoto, R.; Inoguchi, T.; Ogawa, Y. Bilirubin reduces visceral obesity and insulin resistance by suppression of inflammatory cytokines. PLoS ONE 2019, 14, e0223302. [CrossRef]

11. Calder, P.C.; Ahluwalia, N.; Brouns, F.; Buetler, T.; Clement, K.; Cunningham, K.; Esposito, K.; Jonsson, L.S.; Kolb, H.; Lansink, M.; et al. Dietary factors and low-grade inflammation in relation to overweight and obesity. Br. J. Nutr. 2011, 106, S1-S78. [CrossRef] [PubMed]

12. McArdle, M.A.; Finucane, O.M.; Connaughton, R.M.; McMorrow, A.M.; Roche, H.M. Mechanisms of obesity-induced inflammation and insulin resistance: Insights into the emerging role of nutritional strategies. Front. Endocrinol. 2013, 4, 52. [CrossRef] [PubMed]

13. Weisberg, S.P.; McCann, D.; Desai, M.; Rosenbaum, M.; Leibel, R.L.; Ferrante, A.W., Jr. Obesity is associated with macrophage accumulation in adipose tissue. J. Clin. Investig. 2003, 112, 1796-1808. [CrossRef] [PubMed]

14. Xu, H.; Barnes, G.T.; Yang, Q.; Tan, G.; Yang, D.; Chou, C.J.; Sole, J.; Nichols, A.; Ross, J.S.; Tartaglia, L.A.; et al. Chronic inflammation in fat plays a crucial role in the development of obesity-related insulin resistance. J. Clin. Investig. 2003, 112, 1821-1830. [CrossRef]

15. Curat, C.A.; Wegner, V.; Sengenes, C.; Miranville, A.; Tonus, C.; Busse, R.; Bouloumie, A. Macrophages in human visceral adipose tissue: Increased accumulation in obesity and a source of resistin and visfatin. Diabetologia 2006, 49, 744-747. [CrossRef]

16. Castoldi, A.; Naffah de Souza, C.; Camara, N.O.; Moraes-Vieira, P.M. The Macrophage Switch in Obesity Development. Front. Immunol. 2015, 6, 637. [CrossRef]

17. Lumeng, C.N.; Bodzin, J.L.; Saltiel, A.R. Obesity induces a phenotypic switch in adipose tissue macrophage polarization. J. Clin. Investig. 2007, 117, 175-184. [CrossRef]

18. Mantovani, A.; Biswas, S.K.; Galdiero, M.R.; Sica, A.; Locati, M. Macrophage plasticity and polarization in tissue repair and remodelling. J. Pathol. 2013, 229, 176-185. [CrossRef]

19. Kratz, M.; Coats, B.R.; Hisert, K.B.; Hagman, D.; Mutskov, V.; Peris, E.; Schoenfelt, K.Q.; Kuzma, J.N.; Larson, I.; Billing, P.S.; et al. Metabolic dysfunction drives a mechanistically distinct proinflammatory phenotype in adipose tissue macrophages. Cell Metab. 2014, 20, 614-625. [CrossRef]

20. Lumeng, C.N.; Saltiel, A.R. Inflammatory links between obesity and metabolic disease. J. Clin. Investig. 2011, 121, 2111-2117. [CrossRef]

21. Galic, S.; Oakhill, J.S.; Steinberg, G.R. Adipose tissue as an endocrine organ. Mol. Cell. Endocrinol. 2010, 316, 129-139. [CrossRef] 
22. Kang, Y.E.; Kim, J.M.; Joung, K.H.; Lee, J.H.; You, B.R.; Choi, M.J.; Ryu, M.J.; Ko, Y.B.; Lee, M.A.; Lee, J.; et al. The Roles of Adipokines, Proinflammatory Cytokines, and Adipose Tissue Macrophages in Obesity-Associated Insulin Resistance in Modest Obesity and Early Metabolic Dysfunction. PLOS ONE 2016, 11, e0154003. [CrossRef]

23. Kershaw, E.E.; Flier, J.S. Adipose tissue as an endocrine organ. J. Clin. Endocrinol. Metab. 2004, 89, 2548-2556. [CrossRef]

24. Fasshauer, M.; Bluher, M. Adipokines in health and disease. Trends Pharmacol. Sci. 2015, 36, 461-470. [CrossRef]

25. Panee, J. Monocyte Chemoattractant Protein 1 (MCP-1) in obesity and diabetes. Cytokine 2012, 60, 1-12. [CrossRef]

26. Hotamisligil, G.S.; Shargill, N.S.; Spiegelman, B.M. Adipose expression of tumor necrosis factor-alpha: Direct role in obesity-linked insulin resistance. Science 1993, 259, 87-91. [CrossRef] [PubMed]

27. Ruan, H.; Miles, P.D.; Ladd, C.M.; Ross, K.; Golub, T.R.; Olefsky, J.M.; Lodish, H.F. Profiling gene transcription in vivo reveals adipose tissue as an immediate target of tumor necrosis factor-alpha: Implications for insulin resistance. Diabetes 2002, 51, 3176-3188. [CrossRef] [PubMed]

28. Stephens, J.M.; Lee, J.; Pilch, P.F. Tumor necrosis factor-alpha-induced insulin resistance in 3T3-L1 adipocytes is accompanied by a loss of insulin receptor substrate-1 and GLUT4 expression without a loss of insulin receptor-mediated signal transduction. $J$. Biol. Chem. 1997, 272, 971-976. [CrossRef]

29. Mohamed-Ali, V.; Goodrick, S.; Rawesh, A.; Katz, D.R.; Miles, J.M.; Yudkin, J.S.; Klein, S.; Coppack, S.W. Subcutaneous adipose tissue releases interleukin-6, but not tumor necrosis factor-alpha, in vivo. J. Clin. Endocrinol. Metab. 1997, 82, 4196-4200. [CrossRef] [PubMed]

30. Rotter, V.; Nagaev, I.; Smith, U. Interleukin-6 (IL-6) induces insulin resistance in 3T3-L1 adipocytes and is, like IL-8 and tumor necrosis factor-alpha, overexpressed in human fat cells from insulin-resistant subjects. J. Biol. Chem. 2003, 278, 45777-45784. [CrossRef] [PubMed]

31. Senn, J.J.; Klover, P.J.; Nowak, I.A.; Zimmers, T.A.; Koniaris, L.G.; Furlanetto, R.W.; Mooney, R.A. Suppressor of cytokine signaling-3 (SOCS-3), a potential mediator of interleukin-6-dependent insulin resistance in hepatocytes. J. Biol. Chem. 2003, 278, 13740-13746. [CrossRef]

32. Volanakis, J.E. Human C-reactive protein: Expression, structure, and function. Mol. Immunol. 2001, 38, 189-197. [CrossRef]

33. Ebrahimi, M.; Heidari-Bakavoli, A.R.; Shoeibi, S.; Mirhafez, S.R.; Moohebati, M.; Esmaily, H.; Ghazavi, H.; Saberi Karimian, M.; Parizadeh, S.M.; Mohammadi, M.; et al. Association of Serum hs-CRP Levels with the Presence of Obesity, Diabetes Mellitus, and Other Cardiovascular Risk Factors. J. Clin. Lab. Anal. 2016, 30, 672-676. [CrossRef]

34. Ellulu, M.S.; Khaza'ai, H.; Rahmat, A.; Patimah, I.; Abed, Y. Obesity can predict and promote systemic inflammation in healthy adults. Int. J. Cardiol. 2016, 215, 318-324. [CrossRef] [PubMed]

35. Yamauchi, T.; Kamon, J.; Minokoshi, Y.; Ito, Y.; Waki, H.; Uchida, S.; Yamashita, S.; Noda, M.; Kita, S.; Ueki, K.; et al. Adiponectin stimulates glucose utilization and fatty-acid oxidation by activating AMP-activated protein kinase. Nat. Med. 2002, 8, 1288-1295. [CrossRef]

36. Dietze-Schroeder, D.; Sell, H.; Uhlig, M.; Koenen, M.; Eckel, J. Autocrine action of adiponectin on human fat cells prevents the release of insulin resistance-inducing factors. Diabetes 2005, 54, 2003-2011. [CrossRef] [PubMed]

37. Ahima, R.S.; Flier, J.S. Leptin. Annu. Rev. Physiol. 2000, 62, 413-437. [CrossRef]

38. Nakamura, K.; Fuster, J.J.; Walsh, K. Adipokines: A link between obesity and cardiovascular disease. J. Cardiol. 2014, 63, 250-259. [CrossRef] [PubMed]

39. Sonoli, S.S.; Shivprasad, S.; Prasad, C.V.; Patil, A.B.; Desai, P.B.; Somannavar, M.S. Visfatin-A review. Eur. Rev. Med. Pharmacol. Sci. 2011, 15, 9-14.

40. Melissas, J.; Malliaraki, N.; Papadakis, J.A.; Taflampas, P.; Kampa, M.; Castanas, E. Plasma antioxidant capacity in morbidly obese patients before and after weight loss. Obes. Surg. 2006, 16, 314-320. [CrossRef]

41. Ohnaka, K.; Kono, S.; Inoguchi, T.; Yin, G.; Morita, M.; Adachi, M.; Kawate, H.; Takayanagi, R. Inverse associations of serum bilirubin with high sensitivity C-reactive protein, glycated hemoglobin, and prevalence of type 2 diabetes in middle-aged and elderly Japanese men and women. Diabetes Res. Clin. Pract. 2010, 88, 103-110. [CrossRef] [PubMed]

42. Petelin, A.; Jurdana, M.; Jenko Praznikar, Z.; Ziberna, L. Serum Bilirubin Correlates with Serum Adipokines in Normal Weight and Overweight Asymptomatic Adults. Acta Clin. Croat. 2020, 59, 19-29. [CrossRef] [PubMed]

43. Chen, H.; Montagnani, M.; Funahashi, T.; Shimomura, I.; Quon, M.J. Adiponectin stimulates production of nitric oxide in vascular endothelial cells. J. Biol. Chem. 2003, 278, 45021-45026. [CrossRef] [PubMed]

44. Ikeda, N.; Inoguchi, T.; Sonoda, N.; Fujii, M.; Takei, R.; Hirata, E.; Yokomizo, H.; Zheng, J.; Maeda, Y.; Kobayashi, K.; et al Biliverdin protects against the deterioration of glucose tolerance in $\mathrm{db} / \mathrm{db}$ mice. Diabetologia 2011, 54, 2183-2191. [CrossRef] [PubMed]

45. Zhu, H.; Wang, J.; Jiang, H.; Ma, Y.; Pan, S.; Reddy, S.; Sun, X. Bilirubin protects grafts against nonspecific inflammation-induced injury in syngeneic intraportal islet transplantation. Exp. Mol. Med. 2010, 42, 739-748. [CrossRef] [PubMed]

46. Liu, Y.; Li, P.; Lu, J.; Xiong, W.; Oger, J.; Tetzlaff, W.; Cynader, M. Bilirubin possesses powerful immunomodulatory activity and suppresses experimental autoimmune encephalomyelitis. J. Immunol. 2008, 181, 1887-1897. [CrossRef] [PubMed]

47. Jangi, S.; Otterbein, L.; Robson, S. The molecular basis for the immunomodulatory activities of unconjugated bilirubin. Int. J. Biochem. Cell Biol. 2013, 45, 2843-2851. [CrossRef]

48. El-Eshmawy, M.M.; Mahsoub, N.; Asar, M.; Elsehely, I. Association between Total Bilirubin Levels and Cardio-metabolic Risk Factors Related to Obesity. Endocr. Metab. Immune Disord. Drug Targets 2021. [CrossRef] 
49. Dong, H.; Huang, H.; Yun, X.; Kim, D.S.; Yue, Y.; Wu, H.; Sutter, A.; Chavin, K.D.; Otterbein, L.E.; Adams, D.B.; et al. Bilirubin increases insulin sensitivity in leptin-receptor deficient and diet-induced obese mice through suppression of ER stress and chronic inflammation. Endocrinology 2014, 155, 818-828. [CrossRef]

50. Liu, J.; Dong, H.; Zhang, Y.; Cao, M.; Song, L.; Pan, Q.; Bulmer, A.; Adams, D.B.; Dong, X.; Wang, H. Bilirubin Increases Insulin Sensitivity by Regulating Cholesterol Metabolism, Adipokines and PPARgamma Levels. Sci. Rep. 2015, 5, 9886. [CrossRef]

51. Feder, S.; Kandulski, A.; Schacherer, D.; Weiss, T.S.; Buechler, C. Serum Chemerin Does Not Differentiate Colorectal Liver Metastases from Hepatocellular Carcinoma. Int. J. Mol. Sci. 2019, 20, 3919. [CrossRef]

52. Dludla, P.V.; Joubert, E.; Muller, C.J.F.; Louw, J.; Johnson, R. Hyperglycemia-induced oxidative stress and heart diseasecardioprotective effects of rooibos flavonoids and phenylpyruvic acid-2-O-beta-D-glucoside. Nutr. Metab. 2017, 14, 45. [CrossRef]

53. Furukawa, S.; Fujita, T.; Shimabukuro, M.; Iwaki, M.; Yamada, Y.; Nakajima, Y.; Nakayama, O.; Makishima, M.; Matsuda, M.; Shimomura, I. Increased oxidative stress in obesity and its impact on metabolic syndrome. J. Clin. Investig. 2004, 114, 1752-1761. [CrossRef]

54. Sies, H. Oxidative stress: A concept in redox biology and medicine. Redox Biol. 2015, 4, 180-183. [CrossRef] [PubMed]

55. Han, C.Y. Roles of Reactive Oxygen Species on Insulin Resistance in Adipose Tissue. Diabetes Metab. J. 2016, 40, 272-279. [CrossRef] [PubMed]

56. Jankovic, A.; Korac, A.; Buzadzic, B.; Otasevic, V.; Stancic, A.; Daiber, A.; Korac, B. Redox implications in adipose tissue (dys)function-A new look at old acquaintances. Redox Biol. 2015, 6, 19-32. [CrossRef]

57. Den Hartigh, L.J.; Omer, M.; Goodspeed, L.; Wang, S.; Wietecha, T.; O’Brien, K.D.; Han, C.Y. Adipocyte-Specific Deficiency of NADPH Oxidase 4 Delays the Onset of Insulin Resistance and Attenuates Adipose Tissue Inflammation in Obesity. Arterioscler. Thromb. Vasc. Biol. 2017, 37, 466-475. [CrossRef] [PubMed]

58. Han, C.Y.; Umemoto, T.; Omer, M.; Den Hartigh, L.J.; Chiba, T.; LeBoeuf, R.; Buller, C.L.; Sweet, I.R.; Pennathur, S.; Abel, E.D.; et al NADPH oxidase-derived reactive oxygen species increases expression of monocyte chemotactic factor genes in cultured adipocytes. J. Biol. Chem. 2012, 287, 10379-10393. [CrossRef]

59. Murphy, M.P. How mitochondria produce reactive oxygen species. Biochem. J. 2009, 417, 1-13. [CrossRef] [PubMed]

60. Dludla, P.V.; Nkambule, B.B.; Tiano, L.; Louw, J.; Jastroch, M.; Mazibuko-Mbeje, S.E. Uncoupling proteins as a therapeutic target to protect the diabetic heart. Pharmacol. Res. 2018, 137, 11-24. [CrossRef] [PubMed]

61. Hurrle, S.; Hsu, W.H. The etiology of oxidative stress in insulin resistance. Biomed. J. 2017, 40, 257-262. [CrossRef] [PubMed]

62. De Marchi, E.; Baldassari, F.; Bononi, A.; Wieckowski, M.R.; Pinton, P. Oxidative stress in cardiovascular diseases and obesity: Role of p66Shc and protein kinase C. Oxidative Med. Cell. Longev. 2013, 2013, 564961. [CrossRef] [PubMed]

63. Jansen, T.; Daiber, A. Direct Antioxidant Properties of Bilirubin and Biliverdin. Is there a Role for Biliverdin Reductase? Front. Pharmacol. 2012, 3, 30. [CrossRef]

64. Stocker, R.; Yamamoto, Y.; McDonagh, A.F.; Glazer, A.N.; Ames, B.N. Bilirubin is an antioxidant of possible physiological importance. Science 1987, 235, 1043-1046. [CrossRef]

65. Lanone, S.; Bloc, S.; Foresti, R.; Almolki, A.; Taille, C.; Callebert, J.; Conti, M.; Goven, D.; Aubier, M.; Dureuil, B.; et al. Bilirubin decreases nos2 expression via inhibition of $\mathrm{NAD}(\mathrm{P}) \mathrm{H}$ oxidase: Implications for protection against endotoxic shock in rats. FASEB J. 2005, 19, 1890-1892. [CrossRef]

66. Talior, I.; Tennenbaum, T.; Kuroki, T.; Eldar-Finkelman, H. PKC-delta-dependent activation of oxidative stress in adipocytes of obese and insulin-resistant mice: Role for NADPH oxidase. Am. J. Physiol.-Endocrinol. Metab. 2005, 288, E405-E411. [CrossRef]

67. Ziberna, L.; Martelanc, M.; Franko, M.; Passamonti, S. Bilirubin is an Endogenous Antioxidant in Human Vascular Endothelial Cells. Sci. Rep. 2016, 6, 29240. [CrossRef]

68. Vitek, L. Bilirubin as a signaling molecule. Med. Res. Rev. 2020, 40, 1335-1351. [CrossRef]

69. Gross, B.; Pawlak, M.; Lefebvre, P.; Staels, B. PPARs in obesity-induced T2DM, dyslipidaemia and NAFLD. Nat. Rev. Endocrinol. 2017, 13, 36-49. [CrossRef]

70. Stec, D.E.; John, K.; Trabbic, C.J.; Luniwal, A.; Hankins, M.W.; Baum, J.; Hinds, T.D., Jr. Bilirubin Binding to PPARalpha Inhibits Lipid Accumulation. PLOS ONE 2016, 11, e0153427. [CrossRef]

71. Tyagi, S.; Gupta, P.; Saini, A.S.; Kaushal, C.; Sharma, S. The peroxisome proliferator-activated receptor: A family of nuclear receptors role in various diseases. J. Adv. Pharm. Technol. Res. 2011, 2, 236-240. [CrossRef]

72. Kersten, S. Integrated physiology and systems biology of PPARalpha. Mol. Metab. 2014, 3, 354-371. [CrossRef]

73. Gordon, D.M.; Blomquist, T.M.; Miruzzi, S.A.; McCullumsmith, R.; Stec, D.E.; Hinds, T.D., Jr. RNA sequencing in human HepG2 hepatocytes reveals PPAR-alpha mediates transcriptome responsiveness of bilirubin. Physiol. Genom. 2019, 51, $234-240$. [CrossRef] [PubMed]

74. Hinds, T.D., Jr.; Burns, K.A.; Hosick, P.A.; McBeth, L.; Nestor-Kalinoski, A.; Drummond, H.A.; AlAmodi, A.A.; Hankins, M.W.; Vanden Heuvel, J.P.; Stec, D.E. Biliverdin Reductase A Attenuates Hepatic Steatosis by Inhibition of Glycogen Synthase Kinase (GSK) 3beta Phosphorylation of Serine 73 of Peroxisome Proliferator-activated Receptor (PPAR) alpha. J. Biol. Chem. 2016, 291, 25179-25191. [CrossRef] [PubMed]

75. Hinds, T.D., Jr.; Hosick, P.A.; Chen, S.; Tukey, R.H.; Hankins, M.W.; Nestor-Kalinoski, A.; Stec, D.E. Mice with hyperbilirubinemia due to Gilbert's syndrome polymorphism are resistant to hepatic steatosis by decreased serine 73 phosphorylation of PPARalpha. Am. J. Physiol.-Endocrinol. Metab. 2017, 312, E244-E252. [CrossRef] [PubMed] 
76. Gordon, D.M.; Neifer, K.L.; Hamoud, A.A.; Hawk, C.F.; Nestor-Kalinoski, A.L.; Miruzzi, S.A.; Morran, M.P.; Adeosun, S.O.; Sarver, J.G.; Erhardt, P.W.; et al. Bilirubin remodels murine white adipose tissue by reshaping mitochondrial activity and the coregulator profile of peroxisome proliferator-activated receptor alpha. J. Biol. Chem. 2020, 295, 9804-9822. [CrossRef]

77. Hinds, T.D., Jr.; Creeden, J.F.; Gordon, D.M.; Stec, D.F.; Donald, M.C.; Stec, D.E. Bilirubin Nanoparticles Reduce Diet-Induced Hepatic Steatosis, Improve Fat Utilization, and Increase Plasma beta-Hydroxybutyrate. Front. Pharmacol. 2020, $11,594574$. [CrossRef]

78. Gao, J.; He, J.; Zhai, Y.; Wada, T.; Xie, W. The constitutive androstane receptor is an anti-obesity nuclear receptor that improves insulin sensitivity. J. Biol. Chem. 2009, 284, 25984-25992. [CrossRef]

79. Yan, J.; Chen, B.; Lu, J.; Xie, W. Deciphering the roles of the constitutive androstane receptor in energy metabolism. Acta Pharmacol. Sin. 2015, 36, 62-70. [CrossRef] [PubMed]

80. Xiao, L.; Xie, X.; Zhai, Y. Functional crosstalk of CAR-LXR and ROR-LXR in drug metabolism and lipid metabolism. Adv. Drug Deliv. Rev. 2010, 62, 1316-1321. [CrossRef]

81. Huang, W.; Zhang, J.; Chua, S.S.; Qatanani, M.; Han, Y.; Granata, R.; Moore, D.D. Induction of bilirubin clearance by the constitutive androstane receptor (CAR). Proc. Natl. Acad. Sci. USA 2003, 100, 4156-4161. [CrossRef] [PubMed]

82. Yang, H.; Wang, H. Signaling control of the constitutive androstane receptor (CAR). Protein Cell 2014, 5, 113-123. [CrossRef] [PubMed]

83. Xu, J.; Lee, E.S.; Baek, S.H.; Ahn, S.Y.; Kim, S.; Na, K.Y.; Chae, D.W.; Chin, H.J. Effect of bilirubin on triglyceride synthesis in streptozotocin-induced diabetic nephropathy. J. Korean Med Sci. 2014, 29, S155-S163. [CrossRef]

84. Perlstein, T.S.; Pande, R.L.; Beckman, J.A.; Creager, M.A. Serum total bilirubin level and prevalent lower-extremity peripheral arterial disease: National Health and Nutrition Examination Survey (NHANES) 1999 to 2004. Arterioscler. Thromb. Vasc. Biol. 2008, 28, 166-172. [CrossRef]

85. Vitek, L. Bilirubin as a predictor of diseases of civilization. Is it time to establish decision limits for serum bilirubin concentrations? Arch. Biochem. Biophys. 2019, 672, 108062. [CrossRef]

86. McCallum, L.; Panniyammakal, J.; Hastie, C.E.; Hewitt, J.; Patel, R.; Jones, G.C.; Muir, S.; Walters, M.; Sattar, N.; Dominiczak, A.F.; et al. Longitudinal Blood Pressure Control, Long-Term Mortality, and Predictive Utility of Serum Liver Enzymes and Bilirubin in Hypertensive Patients. Hypertension 2015, 66, 37-43. [CrossRef] [PubMed]

87. Creeden, J.F.; Gordon, D.M.; Stec, D.E.; Hinds, T.D., Jr. Bilirubin as a metabolic hormone: The physiological relevance of low levels. Am. J. Physiol.-Endocrinol. Metab. 2021, 320, E191-E207. [CrossRef]

88. Nascimento, H.; Alves, A.I.; Coimbra, S.; Catarino, C.; Gomes, D.; Bronze-da-Rocha, E.; Costa, E.; Rocha-Pereira, P.; Aires, L.; Mota, J.; et al. Bilirubin is independently associated with oxidized LDL levels in young obese patients. Diabetol. Metab. Syndr. 2015, 7, 4. [CrossRef] [PubMed]

89. Eremiasova, L.; Hubacek, J.A.; Danzig, V.; Adamkova, V.; Mrazova, L.; Pitha, J.; Lanska, V.; Cifkova, R.; Vitek, L. Serum Bilirubin in the Czech Population-Relationship to the Risk of Myocardial Infarction in Males. Circ. J. 2020, 84, 1779-1785. [CrossRef]

90. Breimer, L.H.; Wannamethee, G.; Ebrahim, S.; Shaper, A.G. Serum bilirubin and risk of ischemic heart disease in middle-aged British men. Clin. Chem. 1995, 41, 1504-1508. [CrossRef]

91. Fulks, M.; Stout, R.L.; Dolan, V.F. Mortality associated with bilirubin levels in insurance applicants. J. Insur. Med. 2009, 41, 49-53. [PubMed]

92. Baird, I.M. Low-calorie-formula diets-Are they safe? Int. J. Obes. 1981, 5, 249-256. [PubMed]

93. Howard, A.N.; Grant, A.; Edwards, O.; Littlewood, E.R.; McLean Baird, I. The treatment of obesity with a very-low-calorie liquid-formula diet: An inpatient/outpatient comparison using skimmed-milk protein as the chief protein source. Int. J. Obes. 1978, 2, 321-332.

94. Belo, L.; Nascimento, H.; Kohlova, M.; Bronze-da-Rocha, E.; Fernandes, J.; Costa, E.; Catarino, C.; Aires, L.; Mansilha, H.F.; Rocha-Pereira, P.; et al. Body fat percentage is a major determinant of total bilirubin independently of UGT1A1*28 polymorphism in young obese. PLoS ONE 2014, 9, e98467. [CrossRef] [PubMed]

95. Loprinzi, P.D.; Mahoney, S.E. Association between flavonoid-rich fruit and vegetable consumption and total serum bilirubin. Angiology 2015, 66, 286-290. [CrossRef]

96. Figge, A.; Sydor, S.; Wenning, C.; Manka, P.; Assmuth, S.; Vilchez-Vargas, R.; Link, A.; Jahnert, A.; Brodesser, S.; Lucas, C.; et al. Gender and gut microbiota composition determine hepatic bile acid, metabolic and inflammatory response to a single fast-food meal in healthy adults. Clin. Nutr. 2021, 40, 2609-2619. [CrossRef]

97. Pallister, T.; Jackson, M.A.; Martin, T.C.; Glastonbury, C.A.; Jennings, A.; Beaumont, M.; Mohney, R.P.; Small, K.S.; MacGregor, A.; Steves, C.J.; et al. Untangling the relationship between diet and visceral fat mass through blood metabolomics and gut microbiome profiling. Int. J. Obes. 2017, 41, 1106-1113. [CrossRef]

98. Intagliata, S.; Salerno, L.; Ciaffaglione, V.; Leonardi, C.; Fallica, A.N.; Carota, G.; Amata, E.; Marrazzo, A.; Pittala, V.; Romeo, G. Heme Oxygenase-2 (HO-2) as a therapeutic target: Activators and inhibitors. Eur. J. Med. Chem. 2019, 183, 111703. [CrossRef] [PubMed]

99. Pittala, V.; Vanella, L.; Salerno, L.; Di Giacomo, C.; Acquaviva, R.; Raffaele, M.; Romeo, G.; Modica, M.N.; Prezzavento, O.; Sorrenti, V. Novel Caffeic Acid Phenethyl Ester (Cape) Analogues as Inducers of Heme Oxygenase-1. Curr. Pharm. Des. 2017, 23, 2657-2664. [CrossRef] [PubMed] 
100. Suk, J.; Jasprova, J.; Biedermann, D.; Petraskova, L.; Valentova, K.; Kren, V.; Muchova, L.; Vitek, L. Isolated Silymarin Flavonoids Increase Systemic and Hepatic Bilirubin Concentrations and Lower Lipoperoxidation in Mice. Oxidative Med. Cell. Longev. 2019, 2019, 6026902. [CrossRef]

101. Mišan, A.; Petelin, A.; Stubelj, M.; Mandić, A.; Šimurina, O.; Pojić, M.; Milovanović, I.; Jakus, T.; Filipčev, B.; Jenko Pražnikar, Z. Buckwheat-enriched instant porridge improves lipid profile and reduces inflammation in participants with mild to moderate hypercholesterolemia. J. Funct. Foods 2017, 36, 186-194. [CrossRef]

102. Petelin, A.; Kenig, S.; Kopinc, R.; Dezelak, M.; Cernelic Bizjak, M.; Jenko Praznikar, Z. Effects of Royal Jelly Administration on Lipid Profile, Satiety, Inflammation, and Antioxidant Capacity in Asymptomatic Overweight Adults. Evid.-Based Complementary Altern. Med. 2019, 2019, 4969720. [CrossRef] [PubMed]

103. Inoue, Y.; Hara, H.; Mitsugi, Y.; Yamaguchi, E.; Kamiya, T.; Itoh, A.; Adachi, T. 4-Hydroperoxy-2-decenoic acid ethyl ester protects against 6-hydroxydopamine-induced cell death via activation of Nrf2-ARE and eIF2alpha-ATF4 pathways. Neurochem. Int. 2018, 112, 288-296. [CrossRef]

104. Hosick, P.A.; Stec, D.E. Heme oxygenase, a novel target for the treatment of hypertension and obesity? Am. J. Physiol.-Regul. Integr. Comp. Physiol. 2012, 302, R207-R214. [CrossRef]

105. Nicolai, A.; Li, M.; Kim, D.H.; Peterson, S.J.; Vanella, L.; Positano, V.; Gastaldelli, A.; Rezzani, R.; Rodella, L.F.; Drummond, G.; et al. Heme oxygenase-1 induction remodels adipose tissue and improves insulin sensitivity in obesityinduced diabetic rats. Hypertension 2009, 53, 508-515. [CrossRef]

106. Li, M.; Kim, D.H.; Tsenovoy, P.L.; Peterson, S.J.; Rezzani, R.; Rodella, L.F.; Aronow, W.S.; Ikehara, S.; Abraham, N.G. Treatment of obese diabetic mice with a heme oxygenase inducer reduces visceral and subcutaneous adiposity, increases adiponectin levels, and improves insulin sensitivity and glucose tolerance. Diabetes 2008, 57, 1526-1535. [CrossRef]

107. Kim, D.H.; Burgess, A.P.; Li, M.; Tsenovoy, P.L.; Addabbo, F.; McClung, J.A.; Puri, N.; Abraham, N.G. Heme oxygenase-mediated increases in adiponectin decrease fat content and inflammatory cytokines tumor necrosis factor-alpha and interleukin-6 in Zucker rats and reduce adipogenesis in human mesenchymal stem cells. J. Pharmacol. Exp. Ther. 2008, 325, 833-840. [CrossRef] [PubMed]

108. Burgess, A.; Li, M.; Vanella, L.; Kim, D.H.; Rezzani, R.; Rodella, L.; Sodhi, K.; Canestraro, M.; Martasek, P.; Peterson, S.J.; et al. Adipocyte heme oxygenase-1 induction attenuates metabolic syndrome in both male and female obese mice. Hypertension 2010, 56, 1124-1130. [CrossRef]

109. Kim, D.H.; Vanella, L.; Inoue, K.; Burgess, A.; Gotlinger, K.; Manthati, V.L.; Koduru, S.R.; Zeldin, D.C.; Falck, J.R.; Schwartzman, M.L.; et al. Epoxyeicosatrienoic acid agonist regulates human mesenchymal stem cell-derived adipocytes through activation of HO-1-pAKT signaling and a decrease in PPARgamma. Stem Cells Dev. 2010, 19, 1863-1873. [CrossRef] [PubMed]

110. D'Andrea, V.; Perez, L.M.; Sanchez Pozzi, E.J. Inhibition of rat liver UDP-glucuronosyltransferase by silymarin and the metabolite silibinin-glucuronide. Life Sci. 2005, 77, 683-692. [CrossRef]

111. Mohamed, M.E.; Frye, R.F. Effects of herbal supplements on drug glucuronidation. Review of clinical, animal, and in vitro studies. Planta Med. 2011, 77, 311-321. [CrossRef]

112. Saracino, M.R.; Bigler, J.; Schwarz, Y.; Chang, J.L.; Li, S.; Li, L.; White, E.; Potter, J.D.; Lampe, J.W. Citrus fruit intake is associated with lower serum bilirubin concentration among women with the UGT1A1*28 polymorphism. J. Nutr. 2009, 139, 555-560. [CrossRef] [PubMed]

113. Konickova, R.; Vankova, K.; Vanikova, J.; Vanova, K.; Muchova, L.; Subhanova, I.; Zadinova, M.; Zelenka, J.; Dvorak, A.; Kolar, M.; et al. Anti-cancer effects of blue-green alga Spirulina platensis, a natural source of bilirubin-like tetrapyrrolic compounds. Ann. Hepatol. 2014, 13, 273-283. [CrossRef]

114. Jette, M. Habitual exercisers: A blood serum and personality profile. J. Sports Med. 1975, 3, 12-17. [CrossRef] [PubMed]

115. Witek, K.; Scislowska, J.; Turowski, D.; Lerczak, K.; Lewandowska-Pachecka, S.; Pokrywka, A. Total bilirubin in athletes, determination of reference range. Biol. Sport. 2017, 34, 45-48. [CrossRef]

116. Hinds, T.D., Jr.; Creeden, J.F.; Gordon, D.M.; Spegele, A.C.; Britton, S.L.; Koch, L.G.; Stec, D.E. Rats Genetically Selected for High Aerobic Exercise Capacity Have Elevated Plasma Bilirubin by Upregulation of Hepatic Biliverdin Reductase-A (BVRA) and Suppression of UGT1A1. Antioxidants 2020, 9, 889. [CrossRef] [PubMed]

117. Swift, D.L.; Johannsen, N.M.; Earnest, C.P.; Blair, S.N.; Church, T.S. Effect of different doses of aerobic exercise training on total bilirubin levels. Med. Sci. Sports Exerc. 2012, 44, 569-574. [CrossRef]

118. Skrypnik, D.; Ratajczak, M.; Karolkiewicz, J.; Madry, E.; Pupek-Musialik, D.; Hansdorfer-Korzon, R.; Walkowiak, J.; Jakubowski, H.; Bogdanski, P. Effects of endurance and endurance-strength exercise on biochemical parameters of liver function in women with abdominal obesity. Biomed. Pharmacother. 2016, 80, 1-7. [CrossRef] [PubMed]

119. Loprinzi, P.D.; Abbott, K. Physical activity and total serum bilirubin levels among insulin sensitive and insulin resistant U.S. adults. J. Diabetes Metab. Disord. 2014, 13, 47. [CrossRef]

120. Ferrandiz, M.L.; Devesa, I. Inducers of heme oxygenase-1. Curr. Pharm. Des. 2008, 14, 473-486. [CrossRef] [PubMed]

121. Vitek, L.; Bellarosa, C.; Tiribelli, C. Induction of Mild Hyperbilirubinemia: Hype or Real Therapeutic Opportunity? Clin. Pharmacol. Ther. 2019, 106, 568-575. [CrossRef] [PubMed]

122. Muchova, L.; Wong, R.J.; Hsu, M.; Morioka, I.; Vitek, L.; Zelenka, J.; Schroder, H.; Stevenson, D.K. Statin treatment increases formation of carbon monoxide and bilirubin in mice: A novel mechanism of in vivo antioxidant protection. Can. J. Physiol. Pharmacol. 2007, 85, 800-810. [CrossRef] [PubMed] 
123. Dias, S.; Paredes, S.; Ribeiro, L. Drugs Involved in Dyslipidemia and Obesity Treatment: Focus on Adipose Tissue. Int. J. Endocrinol. 2018, 2018, 2637418. [CrossRef] [PubMed]

124. Lozano, R.; Domeque, N.; Apesteguia, A.F. Atazanavir-bilirubin interaction: A pharmacokinetic-pharmacodynamic model. Clin. Pharmacol. 2013, 5, 153-159. [CrossRef]

125. Crane, H.M.; Nance, R.M.; Heckbert, S.R.; Ritchings, C.; Rosenblatt, L.; Budoff, M.; Wood, B.R.; Tirschwell, D.L.; Kim, H.N.; Mathews, W.C.; et al. Association Between Bilirubin, Atazanavir, and Cardiovascular Disease Events among People Living With HIV Across the United States. J. Acquir. Immune Defic. Syndr. 2019, 81, e141-e147. [CrossRef]

126. Dekker, D.; Dorresteijn, M.J.; Pijnenburg, M.; Heemskerk, S.; Rasing-Hoogveld, A.; Burger, D.M.; Wagener, F.A.; Smits, P. The bilirubin-increasing drug atazanavir improves endothelial function in patients with type 2 diabetes mellitus. Arterioscler. Thromb. Vasc. Biol. 2011, 31, 458-463. [CrossRef] [PubMed]

127. Zuperl, S.; Fornasaro, S.; Novic, M.; Passamonti, S. Experimental determination and prediction of bilitranslocase transport activity. Anal. Chim. Acta 2011, 705, 322-333. [CrossRef]

128. Robertson, A.; Brodersen, R. Effect of drug combinations on bilirubin-albumin binding. Dev. Pharmacol. Ther. 1991, 17, 95-99. [CrossRef]

129. Soligard, H.T.; Nilsen, O.G.; Bratlid, D. Displacement of bilirubin from albumin by ibuprofen in vitro. Pediatr. Res. 2010, 67, 614-618. [CrossRef]

130. Kunutsor, S.K. Serum total bilirubin levels and coronary heart disease-Causal association or epiphenomenon? Exp. Gerontol. 2015, 72, 63-66. [CrossRef]

131. Bellarosa, C.; Bedogni, G.; Bianco, A.; Cicolini, S.; Caroli, D.; Tiribelli, C.; Sartorio, A. Association of Serum Bilirubin Level with Metabolic Syndrome and Non-Alcoholic Fatty Liver Disease: A Cross-Sectional Study of 1672 Obese Children. J. Clin. Med. 2021, 10, 2812. [CrossRef] [PubMed]

132. Lippi, G.; Targher, G.; Montagnana, M.; Salvagno, G.L.; Guidi, G.C. Bilirubin concentration and cardiovascular risk profile. Liver Int. 2009, 29, 315-316. [CrossRef] [PubMed] 